\title{
Interleukin 21 treatment in a murine model as a novel potential cytokine immunotherapy for colon cancer
}

\author{
Chen Chen ${ }^{1, A-F}$, Xiaoning Liu' ${ }^{2, A-C, F}$, Yi Ren ${ }^{3, A, B, F}$ \\ ${ }^{1}$ Clinical School, Hubei University of Chinese Medicine, China \\ ${ }^{2}$ Central Laboratory of Huai'an First People's Hospital, Nanjing Medical University, China \\ ${ }^{3}$ Department of Breast and Thyroid Surgery, Huai'an First People Hospital, Nanjing Medical University, China \\ A - research concept and design; $B$ - collection and/or assembly of data; $C$ - data analysis and interpretation; \\ $D$ - writing the article; $E$ - critical revision of the article; $F$ - final approval of the article
}

\section{Address for correspondence}

Chen Chen

E-mail: 44736881@qq.com

Funding sources

None declared

Conflict of interest

None declared

Received on January 7, 2016

Reviewed on November 15, 2016

Accepted on January 28, 2017

\begin{abstract}
Background. Interleukin 21 (IL-21), which belongs to the common $y$-chain ( $ү \mathrm{c})$ family, is a novel tumor suppressor that has been shown to affect T-cell proliferation, survival and function. However, the role of IL-21 in colon cancer remains unclear.
\end{abstract}

Objectives. We sought to determine whether IL-21 could inhibit the progression of colon cancer in mice; we also explored the mechanisms underlying the immunological effects of IL-21 in colon cancer.

Material and methods. Exogenous IL-21 protein was expressed to treat tumor-bearing mice and the production of cytokine interleukin 4, interferon gamma and lambda from $\mathrm{CD}^{+}{ }^{+} \mathrm{T}, \mathrm{CD} 8^{+} \mathrm{T}$, and NK cells were measured, along with the survival times of these tumor-bearing mice.

Results. Interleukin 21 promoted the secretion of interferon gamma from the $C D 4^{+} T, C D 8^{+} T$ and NK cells and it enhanced the production of interferon lambda by the NK cells. More importantly, IL-21 treatment significantly enhanced antitumor effects in favor of tumor eradication. We also found that CD8 $8^{+} T$ and NK cells are necessary for the antitumor immune responses elicited by IL-21.

Conclusions. Interleukin 21 is a powerful tool for activating $C D 8^{+} T$ cells and NK cells which exhibit potent cytolytic effector functions and should therefore be exploited for anticancer immunotherapy. Our findings support the development of a novel cytokine immunotherapy against colon cancer.

Key words: colon cancer, immunotherapy, interleukin 21, interferon y

DOI

10.17219/acem/68703

Copyright

Copyright by Author(s)

This is an article distributed under the terms of the

Creative Commons Attribution Non-Commercial License

(http://creativecommons.org/licenses/by-nc-nd/4.0/) 


\section{Introduction}

Colorectal cancer is the $6^{\text {th }}$ leading cause of tumor-related death in China. ${ }^{1-3}$ Although the treatment of colorectal cancer has significantly improved over the past few years, the results of the current treatment modalities are unsatisfactory, especially for patients in the advanced stages of colon cancer. ${ }^{4,5}$ Therefore, the development of effective therapeutic approaches for colon cancer is necessary. Tumor immunotherapy brings new hope for cancer treatment.

Effective tumor immunotherapy depends on the presence of large numbers of tumor-infiltrating $\mathrm{T}$ lymphocytes with effector functions, appropriate phenotypic characteristics, self-renewal potential, and homing capacity. ${ }^{6-9}$ In addition to $\mathrm{T}$ lymphocytes, $\mathrm{CD}^{+} \mathrm{T}$ cells and natural killer (NK) cells also play an important role in antitumor immune therapy by eliminating tumor cells through the actions of perforin and granzyme. ${ }^{10,11}$ Thus, the ability to elicit the cytotoxicity of $\mathrm{NK}$ cells and $\mathrm{CD}^{+} \mathrm{T}$ would benefit cancer immunotherapy.

Interleukin 21 (IL-21) belongs to the common-gamma chain family, which includes $I L-15, I L-9, I L-7, I L-4$, and $I L-2 .{ }^{12,13}$ These cytokines display a similar 4-helix bundle structure and functional redundancy in their regulation and homeostasis of the lymphoid system, but each family member also performs distinct functions. ${ }^{13,14}$ IL-21 is produced by activated $\mathrm{CD} 4^{+} \mathrm{T}$ cells, NK $\mathrm{T}$ cells and follicular T-helper cells (Th). ${ }^{6}$ Recently, IL-21 has been revealed to exhibit antitumor function in different tumor models and its mechanism of action has been reported to involve the stimulation of $\mathrm{T}$ - or $\mathrm{B}$-cell responses and NK cells. ${ }^{6,10,11,15}$ Moreover, the antitumor activity of IL-21 can be potentiated when it is used in combination with other immunostimulants, chemotherapy, or monoclonal antibodies that recognize tumor antigens. ${ }^{8,13,16}$ For example, the combined use of IL-21 and peptide-loaded dendritic cells increases the number of human Melan-A/ MART-1-specific $\mathrm{CD}^{+} \mathrm{T}$ cells that display high affinity and a CD45RO ${ }^{+} \mathrm{CD} 28^{\text {high }}$ phenotype upon in vitro stimulation. ${ }^{13}$ These results indicate that IL-21 has antitumor activity in vitro.

IL-21 can also enhance the antitumor activity of dendritic-cell vaccines or antibodies. However, for immune-competent murine models of colon cancer, the immunological consequences of IL-21 stimulation have not been addressed so far. Therefore, in this study, we investigated whether IL-21 could suppress the growth of colon cancer in mice; we also tried to elucidate the mechanisms underlying the antitumor immune effects of IL-21. Our findings provide data essential for the development of effective tumor immunotherapies in the future.

\section{Material and methods}

\section{Cell lines and mice}

Mouse colon cancer cells (CT-26 cells) were obtained from the American Type Culture Collection (ATCC) and maintained in Dulbecco's Modification of Eagle's Medium (DMEM) supplemented with 10\% heat-inactivated fetal bovine serum (FBS), $100 \mu \mathrm{g} / \mathrm{mL}$ streptomycin, $100 \mathrm{U} / \mathrm{mL}$ penicillin, and $2 \mathrm{mM} \mathrm{L}$-glutamine (Thermo Fisher Scientific, Shanghai, China). Eight-week-old male BALB/c mice were purchased from the Center of Animal Experiment of Wuhan University, China. The mice used in the experiments were fed under specific pathogen-free conditions in the animal facility of Wuhan University and treated in accordance with the guidelines of the Institutional Animal Care and Use Committee (IACUC) of Wuhan University.

\section{Generation of IL-21-His and GST-His fusion protein}

To generate an IL-21-His fusion protein, total RNA was extracted from the BALB/c mouse splenocytes, using TRIzol (Invitrogen, Shanghai, China), and comolementary DNA (cDNA) was synthesized using an RT-PCR kit (Fermentas, Shenzhen, China). The sequences encoding IL-21 were then amplified using selected primers (Table 1), and the polymerase chain reaction (PCR) product was sequenced and then cloned in-frame between the SalI and HindIII (New England Biolabs, Beijing, China) restriction sites of a pET-20b(+) vector to ensure that the His-tag was fused with IL-21. The pET-20b(+) construct was then transfected into BL21(DE3)pLySs (Merckmillipore, Shanghai, China) cells, which were then induced with $0.1 \mathrm{mM}$ isopropyl $\beta$-D-1-thiogalactopyranoside (IPTG) (Thermo Scientific, Shanghai, China). Next, the fusion proteins were purified using His-Select Nickel Affinity Gel (Sigma-Aldrich, Shanghai, China) or Glutathione Sepharose 4B (GE Healthcare Life Science, Beijing, China), and lipopolysaccharide contamination was removed using DetoxiGelTM Endotoxin Removing Columns (Thermo Scientific, Shanghai, China). The proteins were then dialyzed in phosphate buffer saline (PBS) and analyzed by sodium dodecyl sulfate-polyacrylamide gel electrophoresis (SDS-PAGE) and western blotting. The endotoxin level was $<0.5 \mathrm{EU} / \mathrm{mg}$, as measured using the Limulus Amebocyte Lysate (LAL) assay (BioWhittaker Limulus Amebocyte Assay; Lonza, Basel, Switzerland). We also transfected the pET-32a(+) vector into BL21(DE3)pLySs cells to generate glutathione $S$-transferase (GST)-His fusion protein for use as a negative control.

\section{Western blot analysis}

The purified IL-21-His and GST-His proteins were identified by western blot using rabbit anti-mouse-IL-21 monoclonal antibodies (dilution 1:1000) (Abcam, Shanghai, 
China). HRP-anti-rabbit IgG (dilution 1:5000) (Abcam, Shanghai, China) was used as a secondary antibody. Commercial IL-21 (eBioscience, San Diego, USA) was used as a positive control.

\section{Isolation of NK cells, $\mathrm{CD}^{+} \mathrm{T}$ cells and $\mathrm{CD} 4^{+} \mathrm{T}$ cells}

NK cells, $\mathrm{CD}^{+} \mathrm{T}$ cells and $\mathrm{CD} 4^{+} \mathrm{T}$ cells were isolated from the spleens of the BALB/c mice, using the $\mathrm{BD}^{\mathrm{TM}} \mathrm{IMag}$ mouse NK cells, CD8 ${ }^{+} \mathrm{T}$ and $\mathrm{CD}^{+} \mathrm{T}$ lymphocytes, and enrichment set-DM and the $\mathrm{BD}^{\mathrm{TM}}$ IMagnet (BD Pharmingen, Beijing, China) by negative selection.

\section{Cytokine-specific ELISA}

The serum interferon gamma (IFN- $\gamma$ ) and IL-4 concentrations from the IL-21-immunized mice were measured by ELISA. In brief, $8 \mathrm{BALB} / \mathrm{c}$ mice per group were immunized with IL-21 (50 $\mu \mathrm{g} / \mathrm{mouse})$ through intravenous injection on days 0,7 and 14. The group of mice immunized with GST $(\mathrm{n}=8)$ or PBS $(\mathrm{n}=8)$ was used as the controls. Peripheral blood from the medial canthus of the eye was drawn on days $0,7,14,21$, and 28 . Sera were harvested to analyze the cytokine levels via ELISA test using cytokine-specific kits (eBioscience, San Diego, USA), according to the protocol recommended by the manufacturer.

$\mathrm{CD}^{+} \mathrm{T}, \mathrm{CD} 8^{+} \mathrm{T}$ and NK cells from the mice were treated with IL-21 and the IFN- $\gamma$ production was analyzed using ELI$\mathrm{SA}$. In brief, $\mathrm{CD}^{+}$and $\mathrm{CD}^{+} \mathrm{T}$ cells $\left(1 \times 10^{6}\right.$ cells/well $)$ were purified and stimulated with CD3 antibodies $(20 \mathrm{ng} / \mathrm{mL})$ and CD28 antibodies (10 ng/mL) (BioLegend, Beijing, China) plus either IL-21 $(20 \mu \mathrm{g} / \mathrm{mL})$ or GST $(20 \mu \mathrm{g} / \mathrm{mL})$ for 3 days. NK cells $\left(1 \times 10^{6}\right.$ cells/well $)$ were purified and stimulated with IL-2 protein (10 ng/mL) (BioLegend, Beijing, China) plus either IL-21 $(20 \mu \mathrm{g} / \mathrm{mL})$ or GST $(20 \mu \mathrm{g} / \mathrm{mL})$ for 3 days, and the supernatants $(200 \mu \mathrm{L} /$ well $)$ were then collected for the IFN- $\gamma$ assay using cytokine-specific kits (eBioscience, San Diego, USA).

\section{Intracellular IFN- $\gamma$ assay}

For intracellular cytokine staining of the $\mathrm{CD}^{+} \mathrm{T}, \mathrm{CD} 4^{+} \mathrm{T}$ and NK cells, the mouse splenocytes $\left(2 \times 10^{6}\right.$ cells/well $)$ were treated using concanavalin A (ConA; $3 \mu \mathrm{g} / \mathrm{mL})$ plus IL-21 $(20 \mu \mathrm{g} / \mathrm{mL})$ or GST $(20 \mu \mathrm{g} / \mathrm{mL})$ for 3 days, after which the cells were restimulated with $100 \mathrm{ng} / \mathrm{mL}$ ionomycin (Sigma-Aldrich, St. Louis, USA), $4 \mu \mathrm{g} / \mathrm{mL}$ GolgiPlug (BD
Pharmingen, Beijing, China) and $50 \mathrm{ng} / \mathrm{mL}$ phorbol 12-myristate 13-acetate (PMA) for $4 \mathrm{~h}$. After $4 \mathrm{~h}$, the cells were incubated with anti-CD8, anti-CD4, or anti-NK1.1 monoclonal antibodies, then fixed, permeabilized, stained with anti-IFN- $\gamma$ (BioLegend, Beijing, China), washed, and analyzed by flow cytometry (BD Immunocytometry Systems, San Jose, USA).

\section{Quantitative real-time polymerase chain reaction}

The $\mathrm{CD}^{+} \mathrm{T}, \mathrm{CD}^{+} \mathrm{T}$ and NK cells were purified, and total RNA from these cells was extracted using TRIzol (Invitrogen, Shanghai, China). Next, 250 ng of each extracted RNA sample was used to synthesize cDNA, using the RevertAid First-Strand real-time polymerase chain reaction (RT-PCR) kit (Fermentas, Shenzhen, China). Complementary DNA (cDNA) was amplified using primers listed in Table 1 in a $25-\mu \mathrm{L}$ reaction mixture containing $100 \mathrm{ng}$ of the cDNA template and $12.5 \mu \mathrm{L}$ of SYBR Green PCR Supermix (Bio-Rad, Hercules, USA) in the recommended cycling conditions. ${ }^{17}$ Each transcript was normalized to the amplification levels of glyceraldehyde 3 -phosphate dehydrogenase (GAPDH). IFN- $\lambda$ mRNA levels were quantified using the MyiQ single-color RT-PCR detection system (Bio-Rad, Hercules, USA).

\section{T-cell proliferation assay}

To examine in vitro proliferation, $\left[{ }^{3} \mathrm{H}\right]$-thymidine-incorporation assays were performed. Briefly, splenocytes from wild-type BALB/c mice were cultured in 96-well plates $\left(5 \times 10^{5}\right.$ cells/well) and treated with PBS, GST, or IL-21 $(20 \mu \mathrm{g} / \mathrm{mL})$ for $72 \mathrm{~h}$. [ $\left.{ }^{3} \mathrm{H}\right]$-Thymidine (HTA Co. Ltd, Beijing, China) was then added $16 \mathrm{~h}$ before a 3 -day culture, and proliferation was measured using a scintillation counter (Beckman, California,USA). A stimulation index was used to reveal the fold-increase in proliferation. The stimulation index was calculated as $\mathrm{cpm}_{\text {exp }} / \mathrm{cpm}_{\text {control. }}$

\section{Mouse immunization and tumor challenge}

The BALB/c male mice were challenged with $3 \times 10^{5} \mathrm{CT}$ 26 tumor cells subcutaneously and randomly divided into 3 groups ( $\mathrm{n}=8 \mathrm{mice} / \mathrm{group})$. After 7 days, the mice were immunized with GST-IL-21 by intravenous injection $(50 \mu \mathrm{g} /$ mouse) when palpable tumors formed (3-5 $\mathrm{mm}$ in diameter). Two additional GST-IL-21 protein immunizations

Table 1. Primer sequences

\begin{tabular}{|l|c|c|}
\multicolumn{1}{|c|}{ Gene name } & Forward $\left(5^{\prime}-3^{\prime}\right)$ & Reverse $\left(5^{\prime}-3^{\prime}\right)$ \\
\hline IL-21 & TCGTCGACATGGAGAGGACCCTTGTCTGT & CGAAGCTTTGAGTCACTGGGCACAGG \\
\hline IFN- $\lambda$ & CTTCCAAGCCCACCCCAACT & GGCCTCCAGGACCTTCAGC \\
\hline GAPDH & ACCACAGTCCATGCCATCAC & TCCACCACCCTGTTGCTGTA \\
\hline
\end{tabular}

IL-21 - interleukin 21; IFN- $\lambda$ - interferon $\lambda$; GAPDH - glyceraldehyde 3-phosphate dehydrogenase. 
were performed in the tumor-bearing mice every 7 days after CT26 inoculation. The mice treated with GST or PBS were used as controls. Tumor volumes were surveyed every 2-3 days and calculated using the following formula: $\mathrm{L} 1^{2} \times \mathrm{L} 2 / 2$, where $\mathrm{L} 1$ is the shortest diameter and L2 is the longest diameter. The mice were euthanized when the tumors grew to $12 \mathrm{~mm}$ in diameter. In some experiments, the mice were treated intraperitoneally with CD4 monoclonal antibodies (clone GK1.5; $250 \mu \mathrm{g} /$ mouse), CD8 monoclonal antibodies (clone 2.43; $500 \mu \mathrm{g} / \mathrm{mouse}$ ), anti-NK1.1 monoclonal antibodies (clone PK136; $200 \mu \mathrm{g} /$ mouse), or isotype control antibodies ( $250 \mu \mathrm{g} /$ mouse) 3 times after tumor inoculation (on days 3, 10 and 17).

\section{Statistical analysis}

The data were analyzed by Tukey's multiple comparison test for more than 2 study groups (GraphPad Prism, 5.01). A 2-way ANOVA and a Kaplan-Meier survival analysis were performed in order to determine statistical significance for in vivo tumor therapy. Probability value $\mathrm{p}<0.05$ was considered statistically significant.

\section{Results}

\section{Expression of recombinant fusion proteins IL-21-His and GST-His}

The molecular weight of mouse IL-21 protein is about $20 \mathrm{kDa} .{ }^{13}$ As indicated in Fig. $1 \mathrm{~A}$ and Fig. 1B, the recombinant
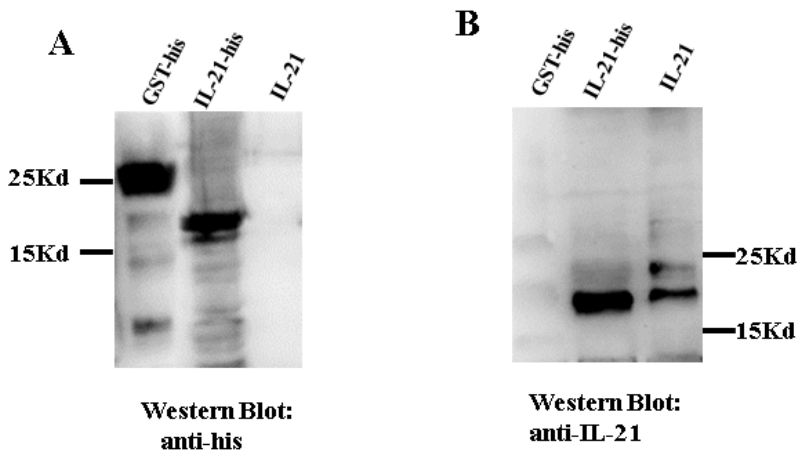

Fig. 1. Identification of the recombinant IL-24-His protein

The proteins IL-21-His and GST-His were purified and then western blotted with $m A$ Abs against His-tag (A) and IL-21 (B); commercial IL-21 protein was used as the positive control.
A

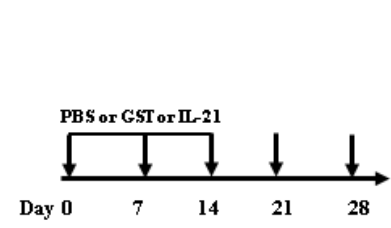

$\mathbf{D}$

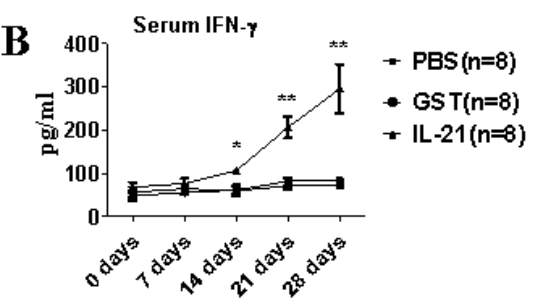

C Serum ILA



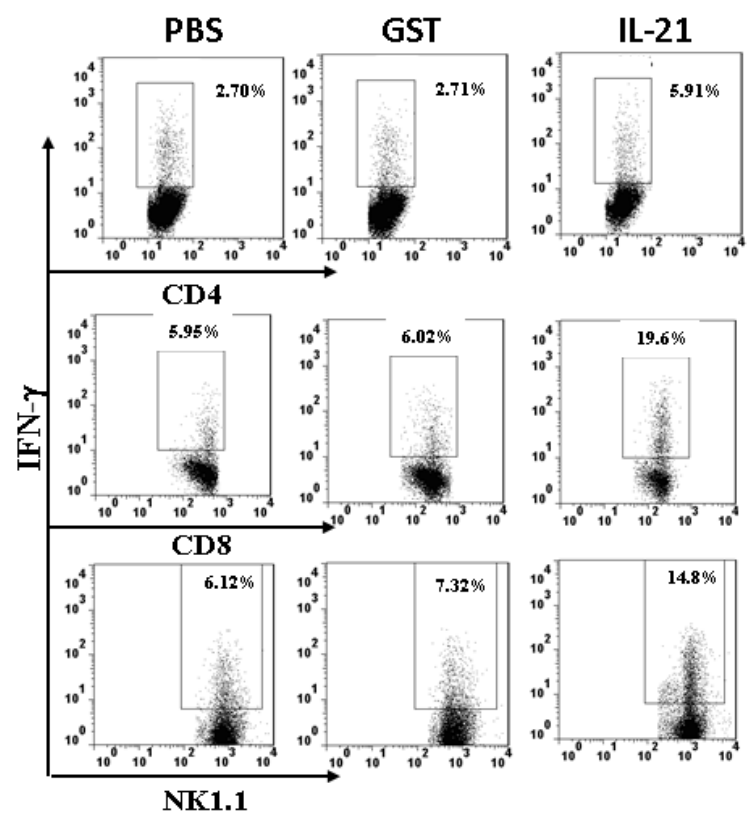
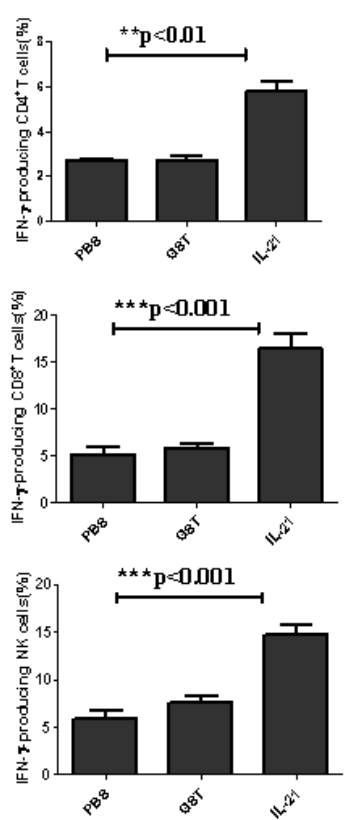

Fig. 2. IL-21-mediated increase in the levels of IFN- $\gamma$ in the serum and splenic IFN- - -producing CD8+ T and NK cells

A - BALB/C mice ( $n=8$ mice/group) were injected 3 times at 1-week intervals with IL-21, GST, or PBS. The sera were then harvested on different days for ELISA analysis of (B) IFN- $\gamma$ and (C) IL-4 cytokine levels. D - splenocytes obtained from the BALB/C mice were stimulated with ConA plus IL-21 for 3 days. The viable splenocytes were then selected, and the CD4+ T, CD8+ T, or NK cells were gated. The percentage (left) and mean fluorescence intensity (MFI) (right) of the IFN- $\gamma$-producing CD4+ T, CD8+ T and NK cells were then analyzed by flow cytometry. Data are representative of 3 experiments. Error bars represent the standard error of the mean; ${ }^{*} p<0.05 ;{ }^{* *} p<0.01 ;{ }^{* * *} p<0.001$. 
IL-21-His fusion protein was blotted positively using His-Tag (Sigma, Shanghai, China) and IL-21 (Abcam, Shanghai, China) monoclonal antibodies. Commercial IL-21 and GST proteins were used as positive and negative controls, respectively.

\section{Interleukin 21 enhances the activation of $\mathrm{CD}^{+} \mathrm{T}$ cells and NK cells}

IFN- $\gamma$ production serves as a marker of effector CD4 ${ }^{+}$ and $\mathrm{CD}^{+} \mathrm{T}$ cells. To determine whether exogenous IL-21 promotes cytokine production in mice, the serum levels of cytokines IFN- $\gamma$ and IL-4 from the mice treated with IL-21 were measured on different days (Fig. 2A). The data revealed that the IFN- $\gamma$ levels were significantly higher in the IL-21-treated mice on days 14, 21 and 28 (p $<0.01$; Fig. 2B) than in the control-treated mice, but the IL-4 levels showed no significant difference at any of the time points in any group (Fig. 2C).

To examine the types of immune cells producing IFN- $\gamma$, we harvested splenocytes from BALB/c mice and analyzed the kinds of IFN- $\gamma$-producing cells by flow cytometry (Fig. 2D). The data suggested that IL-21 injection significantly promoted the production of IFN- $\gamma$-producing $\mathrm{CD}^{+}$ T cells and NK cells ( $<<0.01$; Fig. 2D).

\section{Interleukin 21 directly induces IFN- $\gamma$ production in $\mathrm{CD}^{+}$and $\mathrm{CD} 8^{+} \mathrm{T}$ cells and IFN- $\gamma$ production in NK cells}

We next aimed to further explore whether exogenous IL-21 can directly stimulate these cells to produce IFN- $\gamma$ and found that IL-21 significantly promoted IFN- $\gamma$ secretion in the T cells and NK cells ( $<<0.01$; Fig. 3A). Since IFN- $\gamma$ from NK cells possesses antitumor activity, our next step was to determine whether IL-21 could promote IFN- $\gamma$ production from NK cells. ${ }^{21}$ As shown in Fig. 3B,
IL-21 significantly enhanced IFN- $\gamma$ production in the NK cells. Furthermore, the IL-21 protein, but not PBS or GST, triggered enhanced splenocyte proliferation, as measured by means of $\left[{ }^{3} \mathrm{H}\right]$-thymidine incorporation $(\mathrm{p}<0.05$, Fig. 3C).

\section{Vaccination with interleukin 21 fusion protein produces potent antitumor effects}

$\mathrm{CD}^{+} \mathrm{T}$ cells and NK cells play crucial roles in antitumor immune responses. ${ }^{22}$ Therefore, we aimed to determine whether IL-21 administration could establish antitumor immunity. As shown in Fig. 4B, IL-21 treatment could significantly suppress tumor growth as compared to PBS or GST treatment in the tumor-bearing mice $(\mathrm{p}<0.05)$. Furthermore, we found that IL-21 treatment significantly prolonged the life of the tumor-bearing mice $(\mathrm{p}<0.05$; Fig. 4C).

To further explore the cellular mechanisms associated with IL-21, CD8 ${ }^{+}$cell, CD4 ${ }^{+}$T cell, and/or NK cell, depletions were carried out during the treatment of the mice. The data showed that mice depleted of NK or CD8 ${ }^{+} \mathrm{T}$ cells lost the antitumor functions elicited by IL-21 ( $p<0.05$; Fig. 4D and 4E). However, the tumor size and survival time of the tumor-bearing mice depleted of $\mathrm{CD} 4^{+} \mathrm{T}$ cells remained unchanged in the IL-21-treated mice (Fig. 4D and $4 \mathrm{E})$. These results revealed that $\mathrm{CD}^{+} \mathrm{T}$ cells and NK cells are essential for the antitumor immune responses induced by IL-21.

\section{Discussion}

In our study, the results showed that the cytokine IL-21 has antitumor effects in murine colon cancer models. IL-21 administration enhanced serum IFN- $\gamma$ levels and
A


B

C

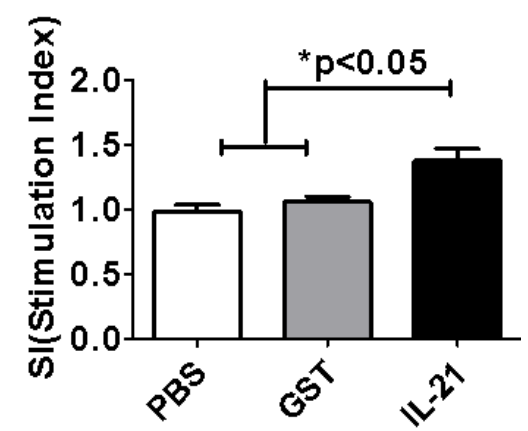

Fig. 3. IL-21 promotes CD8+T cell and NK cell functions

Purified CD4+ T, CD8+ T and NK cells were stimulated with CD3 and CD28 antibodies or IL-2 plus IL-21 or GST for 3 days, and then the supernatants were collected for IFN- $\gamma$ assays (A); B - quantitative analysis of IFN-lambda mRNA-expression levels in the CD4+ T, CD8+ T, or NK cells; C - splenocytes from BALB/C mice were cultured in 96-well plates and stimulated with PBS, GST, or IL-21 for $72 \mathrm{~h}$. [3H]-thymidine was added and proliferation was measured using a scintillation counter; the fold-increase in proliferation is shown using a stimulation index. Data are representative of 3 experiments. Error bars represent the standard error of the mean; ${ }^{*} p<0.05 ;{ }^{* *} p<0.01$; ${ }^{* *} p<0.001$. 
$\mathbf{A}$

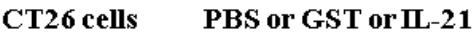

B

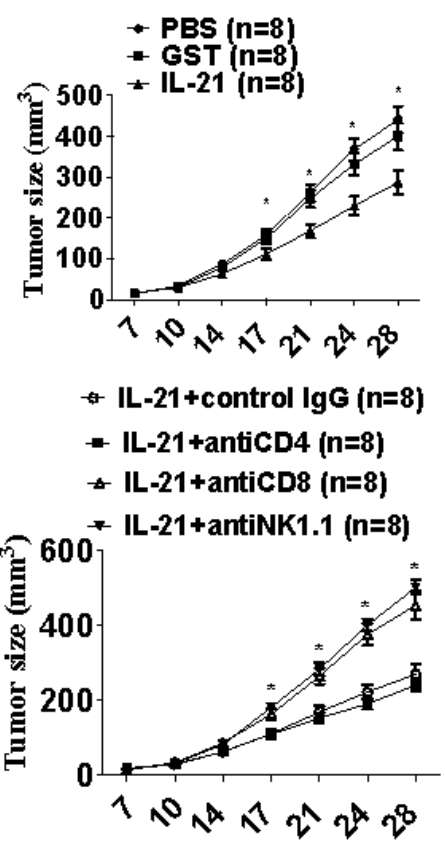



C $\quad-$ PBS $(n=8)$

*IL-21 (n=8)

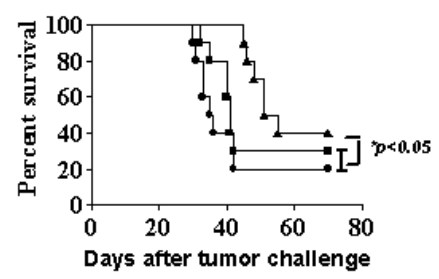

- IL-21+control IgG $(n=8)$

$-I L-21+\operatorname{tanti-CD4}(\mathrm{n}=8)$

$\mathbf{E}$

- IL-21+anti-CD8 ( $n=8)$

$\rightarrow$ IL-21+anti-NK1.1 $(n=8)$

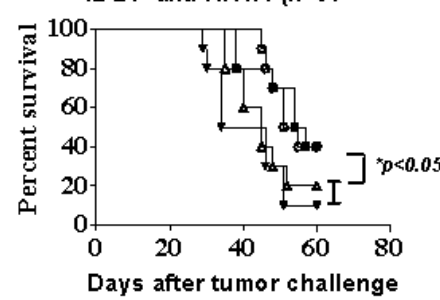

Fig. 4. Reduced tumor burden and enhanced survival rate in tumor-bearing mice following treatment with IL-21

A - schematic of tumor challenge and IL-21 immunization. BALB/c mice were injected subcutaneously with CT-26 tumor cells. After 7 days, the tumor diameter reached 3-4 mm; the mice were then treated 3 times at 1-week intervals with IL-21, GST, or PBS. Tumor growth (B) and survival rate (C) were recorded. D, E - BALB/C mice were challenged subcutaneously with tumor cells and then injected intraperitoneally with anti-CD4 mAb, anti-CD8 mAb, anti-NK1.1 $\mathrm{mAb}$, or isotype control mAb on day 3. The mice were then injected with different proteins The depleting mAb or isotype control mAb was injected 3 days before protein injection. After 3 protein injections, the tumor size and survival rate of the tumor-bearing mice were recorded. Data are representative of 3 experiments. Error bars represent standard error of the mean; ${ }^{*} p<0.05 ;{ }^{* *} p<0.01 ;{ }^{* * *} p<0.001$.
IFN- $\gamma$ secretion in the CD8 ${ }^{+} \mathrm{T}, \mathrm{CD} 4^{+} \mathrm{T}$ and $\mathrm{NK}$ cells. We also established that IL-21 promotes IFN- $\gamma$ secretion from NK cells as well as the proliferation of splenocytes. Moreover, we found that the antitumor function of IL-21 relied on $\mathrm{CD}^{+} \mathrm{T}$ cells and NK cells.

Previous studies have shown that IL-21 markedly suppresses tumor growth in some cancers, including colon cancer, ${ }^{18}$ breast cancer, ${ }^{19}$ melanoma, ${ }^{20}$ and renal cancer. ${ }^{21}$ In these studies, the mechanism underlying the antitumor effect of IL-21 in different tumor models was found to involve the activation of T cells and NK cell responses. Moreover, it was found that the antitumor function of IL-21 could be potentiated when it was used in combination with other immunostimulants, chemotherapy, or monoclonal antibodies that recognize tumor antigens. ${ }^{22-24}$ However, the mechanism by which IL-21 affects T cells and NK cells and exerts antitumor effects has not been previously researched in colon cancer models.

Our data revealed that recombinant IL-21 could directly promote the secretion of IFN- $\gamma$ in $C D 8^{+} \mathrm{T}, \mathrm{CD} 4^{+} \mathrm{T}$ and NK cells. Previously, Zeng and colleagues reported that IL-21 exerts limited effects on the secretion of IFN- $\gamma$ in $\mathrm{CD}^{+} \mathrm{T}$ cells. ${ }^{24}$ However, this does not contradict our data, because IL-21 produces highly limited effects on naïve T cells; in our experiment, we added CD3 and CD28 monoclonal antibodies to activate the $\mathrm{T}$ cells. Zeng et al. also reported that IL-21 produces extremely weak effects on the proliferation of $\mathrm{CD}^{+} \mathrm{T}$ cells, $\mathrm{CD} 4^{+} \mathrm{T}$ cells and NK cells. ${ }^{24}$ In contrast, our results indicated that IL-21 markedly enhanced the proliferation of splenocytes.
We speculate that IL-21 promotes B-cell proliferation because the spleen contains numerous $B$ cells and because the IL-21 receptor (IL-21R) is expressed on B cells. ${ }^{14}$ Thus, our data revealed that the recombinant protein IL-21-His exerted its biological function, but we could not clarify the underlying mechanism. Li et al. previously reported that IL-21R is expressed on the surface of B cells, CD8 ${ }^{+} \mathrm{T}$ cells, CD4 ${ }^{+} \mathrm{T}$ cells, and NK cells. ${ }^{14}$ We speculate that IL-21 could ligate the IL-21R expressed on the surface of $\mathrm{CD}^{+}$and $\mathrm{CD}^{+} \mathrm{T}$ cells, and could thereby activate $\mathrm{T}$ cells.

Further, IFN- $\gamma$ plays very important roles in NK cellmediated tumor destruction pathways. ${ }^{25}$ We therefore measured the changes in the levels of IFN- $\gamma$ in T and NK cells after treatment with IL-21. Our results revealed that IL-21 could not only enhance IFN- $\gamma$ production but could also promote IFN- $\gamma$ production. The data also showed that IL-21 could enhance antitumor immunity in the mice by increasing IFN- $\gamma$ production and activating NK cells.

Thus, we revealed an important role for NK cells and $\mathrm{CD}^{+} \mathrm{T}$ cells in IL-21-mediated antitumor immune responses. Moreover, we found that the antitumor function of IL-21 was lost in the mice depleted of NK cells or $\mathrm{CD}^{+} \mathrm{T}$ cells, but not in those depleted of CD4 ${ }^{+} \mathrm{T}$ cells. Our data also revealed that IL-21 could enhance the secretion of INF- $\gamma$ in CD4 ${ }^{+}$and $C D 8^{+} \mathrm{T}$ cells. However, because of the expression of CD4 molecules on Treg cells, it is possible that injection of the CD4 antibody in mice depleted Treg cells.

The blockade of immune checkpoints in tumor immunotherapy, such as programmed cell death protein 1 (PD1), 
rely on the enhancement of spontaneous antitumor immunity. However, these immunotherapies are limited by the requirement for existing tumor-specific immune responses. ${ }^{26-28}$ Therefore, breaking immune tolerance to the tumor and enhancing the immune response to tumor antigens should increase tumor immunogenicity. Our results strongly suggested that IL-21, serving as a cytokine, promotes tumor-specific immune responses. The findings of some other studies provide further in vivo evidence for the tumor-suppressive function of IL-21. ${ }^{6,12,13,29}$

In summary, our study shows that IL-21 can not only directly enhance the secretion of IFN- $\gamma$ in $\mathrm{CD}^{+} \mathrm{T}$ cells and $\mathrm{CD} 4{ }^{+} \mathrm{T}$ cells, but can also promote the secretion of IFN- $\gamma$ and IFN- $\lambda$ in NK cells and suppress the growth of CT-26 tumor cells. Thus, IL-21 is a powerful tool for activating $\mathrm{CD}^{+} \mathrm{T}$ cells and NK cells which exhibit potent cytolytic effector functions, and should therefore be considered for tumor immunotherapy in the future.

\section{References}

1. Zheng ZX, Zheng RS, Zhang SW, Chen WQ. Colorectal cancer incidence and mortality in China, 2010. Asian Pac J Cancer Prev. 2014;15: $8455-8460$.

2. Liu S, Zheng R, Zhang M, Zhang S, Sun X, Chen W. Incidence and mortality of colorectal cancer in China, 2011. Chin J Cancer Res. 2015;27: 22-28.

3. Chen W, Zheng $R$, Zeng $H$, Zhang $S$. The updated incidences and mortalities of major cancers in China, 2011. Chin J Cancer. 2015;34:53.

4. Guend H, Patel S, Nash GM. Abdominal metastases from colorectal cancer: Intraperitoneal therapy. J Gastrointest Oncol. 2015;6:693-698.

5. Chibaudel B, Tournigand C, Bonnetain F, et al. Therapeutic strategy in unresectable metastatic colorectal cancer: An up-dated review. Ther Adv Med Oncol. 2015;7:153-169.

6. Santegoets SJ, Turksma AW, Powell JDJ, Hooijberg E, de Gruijl TD. IL-21 in cancer immunotherapy: At the right place at the right time. Oncoimmunology. 2013;2:e24522.

7. Leung J, Suh WK. The CD28-B7 family in anti-tumor immunity: Emerging concepts in cancer immunotherapy. Immune Netw. 2014;14:265-276.

8. Phan GQ, Rosenberg SA. Adoptive cell transfer for patients with metastatic melanoma: The potential and promise of cancer immunotherapy. Cancer Control. 2013;20:289-297.

9. Kalos $\mathrm{M}$, June $\mathrm{CH}$. Adoptive T cell transfer for cancer immunotherapy in the era of synthetic biology. Immunity. 2013;39:49-60.

10. Moroz A, Eppolito C, Li Q, Tao J, Clegg CH, Shrikant PA. IL-21 enhances and sustains $\mathrm{CD}^{+} T$ cell responses to achieve durable tumor immunity: Comparative evaluation of IL-2, IL-15, and IL-21. J Immunol. 2004; 173:900-909.

11. Kumano M, Hara I, Furukawa J, et al. Interleukin-21 activates cytotoxic T lymphocytes and natural killer cells to generate antitumor response in mouse renal cell carcinoma. J Urol. 2007;178:1504-1509.

12. Ozaki K, Spolski R, Feng CG, et al. A critical role for IL-21 in regulating immunoglobulin production. Science. 2002;298:1630-1634.

13. Croce M, Rigo V, Ferrini S. IL-21: A pleiotropic cytokine with potential applications in oncology. J Immunol Res. 2015;2015:696578.

14. Li J, Shen W, Kong K, Liu Z. Interleukin-21 induces T-cell activation and proinflammatory cytokine secretion in rheumatoid arthritis. Scand J Immunol. 2006;64:515-522.

15. Santegoets SJ, Turksma AW, Suhoski MM, et al. IL-21 promotes the expansion of $\mathrm{CD} 27^{+} \mathrm{CD} 28^{+}$tumor infiltrating lymphocytes with high cytotoxic potential and low collateral expansion of regulatory T cells. J Trans/ Med. 2013;11:37.

16. Spolski R, Leonard WJ. Interleukin-21: A double-edged sword with therapeutic potential. Nat Rev Drug Discov. 2014;13:379-395.

17. Zhou $L$, Li JL, Zhou $Y$, et al. Induction of interferon- $\lambda$ contributes to TLR3 and RIG-I activation-mediated inhibition of herpes simplex virus type 2 replication in human cervical epithelial cells. Mol Hum Reprod. 2015;21:917-929.
18. Ugai S, Shimozato O, Kawamura K, et al. Expression of the interleukin-21 gene in murine colon carcinoma cells generates systemic immunity in the inoculated hosts. Cancer Gene Ther. 2003;10:187-192.

19. Park YK, Shin DJ, Cho D, et al. Interleukin-21 increases direct cytotoxicity and IFN-gamma production of ex vivo expanded NK cells towards breast cancer cells. Anticancer Res. 2012;32:839-846.

20. Green J, Ariyan C. Update on immunotherapy in melanoma. Surg Oncol Clin N Am. 2015;24:337-346.

21. Curti BD. Immunomodulatory and antitumor effects of interleukin-21 in patients with renal cell carcinoma. Expert Rev Anticancer Ther. 2006;6:905-909.

22. Roda JM, Parihar R, Lehman A, Mani A, Tridandapani S, Carson WE $3^{\text {rd }}$. Interleukin-21 enhances NK cell activation in response to antibodycoated targets. J Immunol. 2006;177:120-129.

23. White L, Krishnan S, Strbo N, et al. Differential effects of IL-21 and IL-15 on perforin expression, lysosomal degranulation, and proliferation in CD8 T cells of patients with human immunodeficiency virus1 (HIV). Blood. 2007;109:3873-3880.

24. Zeng R, Spolski R, Finkelstein SE, et al. Synergy of IL-21 and IL-15 in regulating $C D 8^{+} T$ cell expansion and function. J Exp Med. 2005;201: 139-148.

25. Sato A, Ohtsuki M, Hata M, Kobayashi E, Murakami T. Antitumor activity of IFN-lambda in murine tumor models. J Immunol. 2006;176:76867694.

26. Brahmer JR, Tykodi SS, Chow L, et al. Safety and activity of anti-PD-L1 antibody in patients with advanced cancer. N Eng/ J Med. 2012;366: $2455-2465$.

27. Eroglu Z, Kim DW, Wang X, et al. Long term survival with cytotoxic T lymphocyte-associated antigen 4 blockade using tremelimumab. Eur J Cancer. 2015;51:2689-2697.

28. Fourcade J, Sun Z, Benallaoua M, et al. Upregulation of Tim-3 and PD-1 expression is as-sociated with tumor antigen-specific $C D 8^{+} T$ cell dysfunction in melanoma patients. J Exp Med. 2010;207:2175-2186.

29. Tangye SG. Advances in IL-21 biology - enhancing our understanding of human disease. Curr Opin Immunol. 2015;34:107-115. 